\title{
HLA Class I and II Binding Promiscuity of the T-cell Epitopes in Putative Proteins of Hepatitis B Virus
}

\author{
Vijai Singh ${ }^{1}$, Indramani ${ }^{2}$, \\ Dharmendra Kumar Chaudhary ${ }^{2}$, Pallavi Somvanshi ${ }^{*} *$
}

${ }^{1}$ Bioinformatics Centre, Biotech Park, Sector-G Jankipuram, Lucknow-226021

${ }^{2}$ National Bureau of Fish Genetic Resources, Lucknow-226002

*Corresponding author: Pallavi Somvanshi, Bioinformatics Centre, Biotech Park, Sector-G, Jankipurum, Lucknow (India), Tel +91 522 4012078;

Email:psomvanshi@gmail.com

Received January 20, 2009; Accepted February 25, 2009; Published February 27, 2009

Citation: Vijai S, Indramani, Dharmendra KC, Pallavi S (2009) HLA Class I and II Binding Promiscuity of the T-cell Epitopes in Putative Proteins of Hepatitis B Virus. J Comput Sci Syst Biol 2: 069-073. doi:10.4172/jcsb.1000018

Copyright: (C) 2009 Vijai S, et al. This is an open-access article distributed under the terms of the Creative Commons Attribution License, which permits unrestricted use, distribution, and reproduction in any medium, provided the original author and source are credited.

\begin{abstract}
Hepatitis B virus is a human infectious disease universally caused by the hepatitis B virus. Its genome size is $3.215 \mathrm{~kb}$. Immunoinformatics tools have been used to predict the epitopes from seven putative protein viz. polymerase, large-S- and middle -S- Protein, S and X-protein, Precore/Core Protein, Core and E- antigen. Total 50 epitopes were predicted for MHC class I and 55 epitopes for class II MHC molecules. These epitopes showed highest binding score at optimum threshold. Epitopes may use as an antigen for diagnosis and also might be helpful for designing peptide based subunit vaccine against Hepatitis $B$ virus.
\end{abstract}

Keywords: Hepatitis B virus; Epitopes; Diagnosis; Vaccine

\section{Introduction}

Hepatitis B virus (HBV) is a dsDNA, enveloped virus that replicates in hepatocytes and belongs to family of the Hepadnavirus. The disease, originally known as "serum hepatitis (Barker et al., 1996) has caused epidemics in various parts of Asia and Africa, and is endemic in China. (Williams, 2006). The primary routes of transmission are through vertical transmission, blood and sexual exposure. Hepatitis $\mathrm{B}$ is potentially a life-threatening liver infection caused by hepatitis B virus. It can cause chronic liver disease and lay people at high risk of death from liver cirrhosis and cancer (Chang, 2007). It is significantly more transmissible than HIV via blood-borne exposure, and some fluids that do not normally transmit HIV viz. saliva and sweat they contain infectious HBV but at lower levels when compared with blood. In many instances, patient route of infection is not identified. About one- third of world's population has been in- fected with the hepatitis B virus. This includes 350 million chronic carriers of the virus. The acute illness causes liver inflammation, vomiting, jaundice and death (WHO report).

Highly pathogenic and communicable virus cannot be cultured easily as it always requires high level of biosafety containment facilities. The culture of hepatitis B virus also requires the cell line for growth and all these steps are time consuming and laborious. Therefore, antigen preparation of hepatitis B virus is not easily processed. Several immunoinformatics tools are available for prediction and mapping of antigenic epitopes in protein sequence. It assist in designing subunit vaccines that starts from prediction of antigenic epitope through in silico techniques from protein sequence of pathogens independent of their abundance and without need to grow the microorganism in vitro (de Groot 
and Rappuoli, 2004; Rappuoli, 2001).

Putative proteins of $M$. tuberculosis were predicted for cytoplasmic, integral membrane, secretory protein attached to membrane by Lipid anchor in the subcellular localization. The predictions provide a method to annotate Mycobacterium proteomes with subcellular localization information rapidly (Somvanshi, et al., 2008a). Several proteins are involved in the pathogenesis and regulation of bacterial cell activity. The prediction of protein subcellular localization was used to distinguish the location in cells in V. cholerae. These proteins reside in cytoplasm, periplasm, inner membrane, outer membrane and extracellular space (Somvanshi et al., 2008b).

Prediction of epitopes in putative protein of hepatitis B virus with Propred and Propred1 are the new strategies to produce antigens for diagnosis. Synthetic peptides can use as vaccines to induce either humoral or cell-mediated immunity requires an understanding of the nature of T-cell and B-cell epitopes has been reported (Singh and Raghava, 2001; Bhasin et al., 2003; Singh and Raghava, 2003). The present study was aimed to predict and map the antigenic epitopes in hepatitis B virus.

\section{Material and Methods}

Bioinformatics tools were used for the analysis of genome of hepatitis B virus. The complete sequences of hepatitis B virus (NC_003977) were retrieved from www.ncbi.nlm.nih.gov. The open reading frames were identified from the whole genome using softwares viz. Generunner, ORF finder and DNAstar. The expected molecular weight, and isoelectric point (pI) value were also verified using Generunner and ExPaSy (http:// www.expasy.org/). Propred (http://www.imtech.res.in/
Research Article JCSB/Vol.2 January-February 2009

raghava/propred/) and Propred1 (http://www.imtech.res.in/ raghava/propred1/) immunoinformatics tools are available to predict the antigenic epitopes in the complete protein primary sequences. Significant efforts have been made in the last few years as several groups devoted their research toward the development of procedures and algorithms that allow more effective and accurate prediction of $\mathrm{MHC}$ binding affinity.

The tools cover maximum number of human leukocyte antigen (HLA) in comparison to other epitope prediction tools. All these epitopes were predicted on the 4\% threshold level with the highest binding score with the MHC molecules. T-cells interact through their polymorphic $\mathrm{T}$ cell receptor with HLA class I molecules containing endogenously synthesized peptides of 9-11 on the surface of infected cells. The presence of allele-specific amino acid motifs has been demonstrated by sequencing of peptides eluted from MHC molecules. Prediction of T-cell epitopes from protein sequence and have been widely used by experimental researchers without expert knowledge of bioinformatics (Lund et al., 2002).

\section{Results and Discussion}

In the present study, seven putative proteins of hepatitis $B$ virus were used for the physicochemical analysis such as molecular weight, isoelectric point ( $\mathrm{pI}$ value) and antigenic nature. The polymerase protein has the highest molecular weight $94.60 \mathrm{kDa}$ and the lowest molecular weight 16.51 $\mathrm{kDa}$ was present in $\mathrm{X}$ - protein. Isoelectric points of these proteins were ranged between 7.87 to 9.94 . The physicochemical propertievs of putative proteins were given (Table 1). The pI value of any protein indicates the stability of protein in that particular isoelectric point.

\begin{tabular}{|l|l|l|l|}
\hline Putative proteins & Accession number & Expected M.W. (kDa) & pI value \\
\hline Polymerase & NP647604 & 94.604 & 9.83 \\
\hline Large-S- Protein & YP355333 & 43.673 & 7.87 \\
\hline Middle -S- Protein & YP355334 & 31.154 & 8.02 \\
\hline S- Protein & NP647605 & 25.381 & 7.85 \\
\hline X- protein & NP647606 & 16.510 & 8.26 \\
\hline Precore/Core Protein & YP355335 & 24.291 & 9.29 \\
\hline Core and e- antigen & NP647607 & 21.097 & 9.94 \\
\hline
\end{tabular}

Table 1: Physicochemical properties of different putative proteins of Hepatitis B virus. 


\begin{tabular}{|c|c|c|c|c|c|c|}
\hline Protein & T-cell epitopes & $\begin{array}{l}\text { Amino } \\
\text { acid } \\
\text { position }\end{array}$ & $\begin{array}{l}\text { No. of MHC } \\
\text { Class II } \\
\text { binding alleles }\end{array}$ & T-cell epitopes & $\begin{array}{l}\text { Amino } \\
\text { acid } \\
\text { position }\end{array}$ & $\begin{array}{l}\text { No. of MHC } \\
\text { Class I } \\
\text { binding alleles }\end{array}$ \\
\hline \multirow{16}{*}{ Polymerase } & VRRAFPHCL & $536-544$ & 03 & FLLSLGIHL & $573-581$ & 10 \\
\hline & VVLSRKYTS & $750-758$ & 22 & GLQPQQGSL & $224-232$ & 03 \\
\hline & LVVDFSQFS & $387-395$ & 11 & FAVPNLQSL & $407-415$ & 08 \\
\hline & VVLGAKSVQ & $552-560$ & 07 & FYPNLTKYL & $115-123$ & 04 \\
\hline & FNPDWKTPS & $69-77$ & 07 & VSPSVPSHL & $818-826$ & 04 \\
\hline & YKRETTRSA & $157-165$ & 03 & MRGTFVAPL & $715-723$ & 05 \\
\hline & LQSLTNLLS & $411-419$ & 11 & ARVTGGVFL & $367-375$ & 06 \\
\hline & LVFQTSTRH & 183-191 & 07 & FSYMDDVVL & $547-555$ & 05 \\
\hline & IGSWGTLPQ & $599-607$ & 11 & LPIHTAELL & $723-731$ & 10 \\
\hline & LNLYPVARQ & $681-689$ & 10 & LPRLADEGL & $25-33$ & 05 \\
\hline & FGRKLHLYS & $496-504$ & 06 & RPTTGRTSL & $807-815$ & 05 \\
\hline & IVQKLKQCF & $610-618$ & 07 & DATPTGWGL & $700-708$ & 03 \\
\hline & FRKLLLLDD & $7-15$ & 05 & RSRSGAKLI & $737-745$ & 03 \\
\hline & YVSLLLLYK & $486-494$ & 12 & CSRNLYVSL & $482-490$ & 03 \\
\hline & YRPLLHLPF & $797-805$ & 07 & & & \\
\hline & YQHFRKLLL & $4-12$ & 09 & & & \\
\hline \multirow{7}{*}{$\begin{array}{l}\text { Large-S- } \\
\text { Protein }\end{array}$} & FLPLLPIFF & $385-393$ & 05 & FLFILLLCL & $257-265$ & 14 \\
\hline & LRRFIIFLF & $250-258$ & 16 & SLDSWWTSL & $205-213$ & 07 \\
\hline & VNPVPTTAS & $150-158$ & 06 & SSWAFARFL & $328-336$ & 08 \\
\hline & FVQWFVGLS & $352-360$ & 08 & LYNILSPFL & $379-387$ & 04 \\
\hline & FLLTRILTI & $193-201$ & 05 & MESTTSGFL & $175-183$ & 04 \\
\hline & LIFLLVLLD & $264-272$ & 10 & GFFLLTRIL & $192-200$ & 05 \\
\hline & \multicolumn{3}{|l|}{ 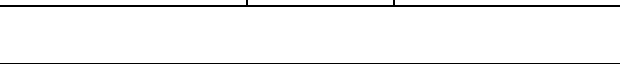 } & WSPQAQGIL & $77-85$ & 05 \\
\hline \multirow{7}{*}{$\begin{array}{l}\text { Middle -S- } \\
\text { Protein }\end{array}$} & LRRFIIFLF & 131-139 & 16 & FLFILLLCL & 138-146 & 15 \\
\hline & FVQWFVGLS & $233-241$ & 08 & SLDSWWTSL & $86-94$ & 06 \\
\hline & FLLTRILTI & $74-82$ & 07 & SSWAFARFL & $209-217$ & 07 \\
\hline & VNPVPTTAS & $31-39$ & 06 & LYNILSPFL & $260-268$ & 06 \\
\hline & LGPLLVLQA & $63-71$ & 06 & MESTTSGFL & $56-64$ & 07 \\
\hline & LIFLLVLLD & $145-153$ & 10 & GFLGPLLVL & $62-70$ & 03 \\
\hline & FLPLLPIFF & $266-274$ & 05 & & & \\
\hline \multirow[t]{4}{*}{ S- Protein } & LRRFJIFLF & $76-84$ & 17 & FLFILLLCL & $83-91$ & 16 \\
\hline & FVQWFVGLS & 178-186 & 08 & SLDSWWTSL & $31-39$ & 06 \\
\hline & FLLTRILTI & $19-27$ & 07 & SSWAFARFL & $154-162$ & 07 \\
\hline & LGPLLVLQV & $8-16$ & 06 & LYNILSPFL & $205-213$ & 06 \\
\hline
\end{tabular}


Journal of Computer Science \& Systems Biology - Open Access

Research Article JCSB/Vol.2 January-February 2009

\begin{tabular}{|c|c|c|c|c|c|c|}
\hline & LIFLLVLLD & $90-98$ & 10 & MESTTSGFL & $1-9$ & 04 \\
\hline & FLPLLPIFF & $211-219$ & 05 & GFFLLTRIL & $18-26$ & 05 \\
\hline \multirow{6}{*}{$X$ - protein } & LRGLPVCAF & $54-62$ & 26 & TTVNAHQVL & $81-89$ & 05 \\
\hline & LRFTSARSM & $70-78$ & 11 & EIRLKVFVL & $126-134$ & 08 \\
\hline & VNAHQVLPK & $82-90$ & 07 & CLFKDWEEL & $115-123$ & 07 \\
\hline & VLHKRTLGL & $91-99$ & 11 & FSSAGPCAL & $63-72$ & 06 \\
\hline & LCLRPVGAE & $15-23$ & 03 & SPSSSAVPA & $39-47$ & 08 \\
\hline & LKVFVLGGC & $128-136$ & 03 & & & \\
\hline \multirow{4}{*}{$\begin{array}{l}\text { Precore/Core } \\
\text { Protein }\end{array}$} & LVVSYVNVN & $112-120$ & 10 & KEFGASVEL & $36-44$ & 07 \\
\hline & VRRRGRSPR & $177-185$ & 07 & LTFGRETVL & $137-145$ & 08 \\
\hline & FGRETVLEY & $138-146$ & 04 & DLLDTASAL & $58-66$ & 05 \\
\hline & $\begin{array}{l}\text { LVSFGVWIR } \\
\end{array}$ & $147-155$ & 12 & LCWGELMNL & $89-97$ & 07 \\
\hline & LMNLATWVG & 93-101 & 04 & YRPPNAPIL & 161-169 & 06 \\
\hline & LKIROLLWF & $123-131$ & 16 & LPSDFFPSI & $48-56$ & 09 \\
\hline & VELLSFLPS & $41-49$ & 03 & & & \\
\hline \multirow{7}{*}{$\begin{array}{l}\text { Protein Core } \\
\text { and e antigen }\end{array}$} & LVVSYVNVN & $83-91$ & 10 & KEFGASVEL & $7-15$ & 08 \\
\hline & VRRRGRSPR & $148-156$ & 07 & LTFGRETVL & $108-116$ & 04 \\
\hline & $\begin{array}{l}\text { LVSFGVWIR } \\
\end{array}$ & $118-126$ & 12 & DLLDTASAL & $29-37$ & 05 \\
\hline & LMNLATWVG & 64-74 & 07 & LCWGELMNL & $60-68$ & 06 \\
\hline & WFHISCLTF & $101-109$ & 08 & YRPPNAPIL & $132-140$ & 06 \\
\hline & LKIRQLLWF & 94-102 & 16 & LPSDFFPSI & $19-27$ & 08 \\
\hline & VELLSFLPS & $12-20$ & 03 & & & \\
\hline
\end{tabular}

Table 2: The predicted epitopes in the putative proteins of Hepatitis B virus.

The prediction of epitopes in Polymerase, large-s- protein, middle -s- Protein, s- protein, $\mathrm{x}$ - protein, precore/core protein, core and e- antigen, proteins of hepatitis $\mathrm{B}$ virus were investigated. Total 50 epitopes were predicted for class I MHC and 55 epitopes for class II MHC molecules in these proteins. The predicted epitopes having the MHC alleles for putative proteins from hepatitis B virus were performed (Table 2). Evaluation of synthetic peptides as potential vaccine candidate for flavivirus has been investigated. Using the computational tools for prediction of epitopes and synthetic peptides from E glycoprotein of Murray Valley encephalitis (MVE) and DEN 2 viruses were prepared and their immunogenicity was evaluated in mice (Gao et al., 1990). The identification of significant T-cells epitopes from secretory and cell surface proteins virulent proteins of $M$. tuberculosis $\mathrm{H} 37 \mathrm{Rv}$ strain was done. The promiscuous nanomer candidate epitopes from HTL and CTL were recognized (Somvanshi et al., 2008a). T-cell analyses of syn- thetic peptides to other viruses have correlated the association between T- and B-cell responses (Hu et al., 1999). A new approach for vaccine design in immunology and the development of bioinformatics tools for $\mathrm{T}$ cell epitope prediction from primary protein sequences is essential. Bioinformatics tools have the potential to accelerate research into the design of vaccines and diagnostic tests by exploiting genome sequences. In silico analysis could be combined with in vitro screening methods to identify the peptides that are immunogenic. Chemically synthesized domains of FMDV (Food-mouth disease virus) VP1 were tested as potential peptide vaccine. The peptide corresponding to amino acid 141-160, 151-160 and 200-213 which are located near the C- terminal end of VP1 and 9-24, 17-32 and 25-41, and the N-terminal end of the VP1, were each bound to a separate insert carrier protein (Bittle et al., 1982).

The prediction of T-cells epitopes in highly virulence sur- 
Research Article JCSB/Vol.2 January-February 2009

face proteins i.e. hemagglutinin and neuraminidase from Influenza A virus H5N1 was performed. The highly conserved and specific epitopes were predicted the Influenza host and strain specific. These epitopes were used for the immunodiagnostic of Influenza and also as a novel epitope based vaccine candidate (Somvanshi et al., 2008c). Immunoinformatics serves as a valuable tool to screen and select antigenic peptide sequences as potential $\mathrm{T}$ cell epitopes for binding affinity with HLA alleles. The dengue variants structural protein was studied and promiscuous nanomer candidate epitope for MHC class I and II has been recognized (Somvanshi and Seth, 2008).

\section{Conclusion}

New theoretical and immunoinformatic approaches are currently used for prediction of epitopes in the proteins sequence of hepatitis B virus without using their cultures. The prediction of hepatitis B virus nanomer epitope for T-cells is recognized against MHC Class II and MHC class I. It may use as an easy and effective way to diagnose the suspected individuals during a future hepatitis B virus epidemic, thereby reducing and containing the transmission. These epitopes may also use for the vaccination against hepatitis B virus.

\section{References}

1. Barker LF, Shulman NR, Murray R, et al. (1996) Transmission of serum hepatitis. 1970 JAMA 276: 841-4. " CrossRef » Pubmed " Google Scholar

2. Bhasin M, Singh H, Raghava GPS (2003) MHCBN: a comprehensive database of MHC binding and non-binding peptides. Bioinformatics 19: 666-667. »CrossRef " Pubmed " Google Scholar

3. Chang MH (2007) Hepatitis B virus infection. Semin Fetal Neonatal Med 12: 160-7. " CrossRef » Pubmed » Google Scholar

4. De Groot AS, Rappuoli R (2004) Genome-derived vaccines. Expert Rev Vaccines 3: 59-76» Pubmed » Google Scholar

5. Hu GJ , Wang RYH, Han DS, Alter HJ, Shih JWK (1999) Characterization of the humoral and cellular immune responses against hepatitis $\mathrm{C}$ virus core induced by DNA-based immunization. Vaccine 17: 3160-3170. " CrossRef » Pubmed » Google Scholar

6. Lund O, Nielsen M, Kesmir C, Christensen JK, Lundegaard C, et al. (2002) Web-based tools for vaccine design. In HIV Molecular Immunlogy (Los Alamos, NM, LA-UR 03-5816: Theoretical Biology and Biophysics Group. Los Alamos National Laboratory pp45-51.

7. Rappuoli R (2001) Reverse vaccinology, a genome-based approach to vaccine development. Vaccine 19: 26882691. " CrossRef » Pubmed » Google Scholar

8. Singh H, Raghava GPS (2001) ProPred: prediction of HLA-DR binding sites. Bioinformatics 17: 1236-1237. " CrossRef " Pubmed " Google Scholar

9. Singh H, Raghava GPS (2003) ProPred1: prediction of promiscuous MHC class-I binding sites. Bioinformatics 19: 1009-1014. » CrossRef » Pubmed » Google Scholar

10.Somvanshi P, Seth PK (2009) Prediction of T cell epitopes for the utility of vaccine development from the structural proteins of dengue virus variants using in silico methods. Indian J Biotechnol (In Press). » Google Scholar

11. Somvanshi P, Singh V, Seth PK (2008a) In silico prediction of epitopes in virulence proteins of Mycobacterium tuberculosis $\mathrm{H} 37 \mathrm{Rv}$ for diagnostic and subunit vaccine design. J Proteomics \& Bioinformatics 1: 143-153. » Google Scholar

12. Somvanshi P, Singh V, Seth PK (2008b) Prediction of epitopes in hemagglutinin and neuraminidase proteins of influenza A virus H5N1 strain: A clue for diagnostic and vaccine development. J Integrative Biology 12: 61-69. "CrossRef " Pubmed " Google Scholar

13. Somvanshi P, Singh V, Seth PK (2008c) Assessing the precision of high-throughput computational approaches for the genome-wide subcellular localization of putative proteins from Vibrio cholerae. The Internet Journal of Genomics and Proteomics 3(2).» CrossRef » Google Scholar

14. Somvanshi P, Singh V, Seth PK (2008) In silico analysis of subcellular localization of putative proteins of $M y$ cobacterium tuberculosis $\mathrm{H} 37 \mathrm{Rv}$ strain. The Internet Journal of Health 7(1).

15. Somvanshi P, Singh V, Seth PK (2008) Phylogenetic and computational proteome analysis of Influenza A virus subtype H5N1. The Internet Journal of Genomics and Proteomics 3(2). » CrossRef » Google Scholar

16. Williams R (2006) Global challenges in liver disease. Hepatology 44: 521-6. " CrossRef » Pubmed » Google Scholar

17.FAQ about Hepatitis B, Stanford University School of Medicine. 